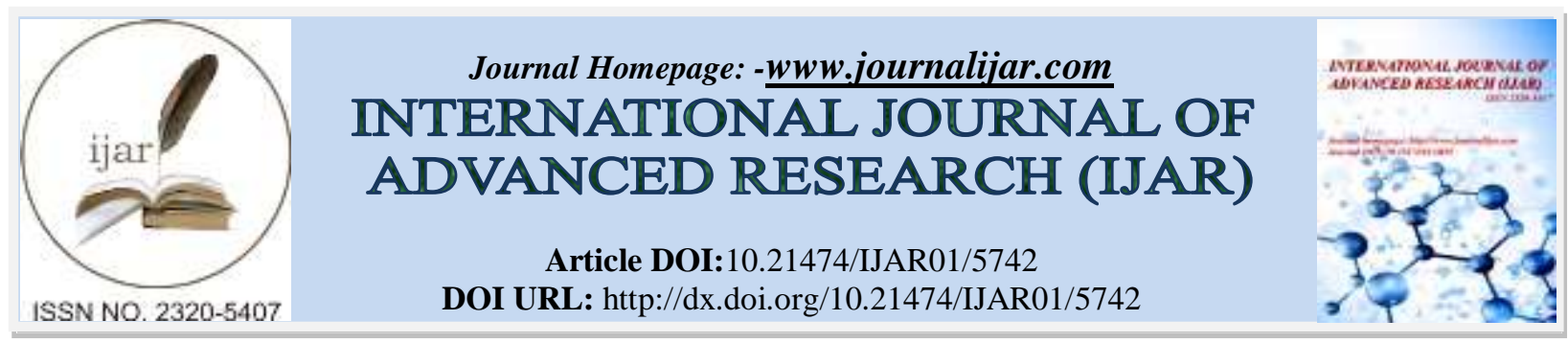

RESEARCH ARTICLE

\title{
THE EFFICACY OF PLATFORM-SWITCHING IN IMPROVING IMPLANT STABILITY.A SYSTEMATIC REVIEW AND META-ANALYSIS.
}

\author{
Asmaa Serag Eldien ${ }^{1}$ and Marwa Amr Alnawawy². \\ 1. BDS, MSc., Assistant lecturer, $6^{\text {th }}$ of October University, Department of Periodontology. \\ 2. BDS, MSc., Assistant lecturer, Cairo University, Department of Periodontology.
}

\section{Manuscript Info}

Manuscript History

Received: 02 September 2017

Final Accepted: 04 October 2017

Published: November 2017

\begin{abstract}
Aim: This study systematically reviews the effect of platformswitching (PS), in immediate implants, on final marginal bone level (MBL) and implant survival in comparison to regular implant abutments

Methods: The authors conducted a Pubmed search till and including August 2017. The review authors independently screened, reviewed and assessed the studies for the risk of bias. This was followed by data extraction and analysis of different outcomes gathered for metaanalysis. Due to expected heterogeneity, we adopted the random-effects model for the conduction of the meta-analysis.

Results: We combined the outcomes of the finally included three studies in a meta-analysis, and it showed a statistically significant difference in favor of the use of PS implants for bone preservation(95\% CI $-0.41 ;-0.19, \mathrm{P}<0.00001)$.

Conclusions: platform-switching seems to improve implant stability and survival through reducing post-surgical marginal bone loss that occurs after functional loading.
\end{abstract}

Copy Right, IJAR, 2017,. All rights reserved.

\section{Introduction:-}

An implant-supported fixed prosthesis for the rehabilitation of a single tooth in the anterior maxilla has become a successful and predictable treatment modality(Schropp et al. 2003; Cooper et al. 2007).

Clinicians have focused their attention on parameters that may influence the interaction between an implant and the underlying hard and soft tissues and thus the predictability of esthetic results over time(Henriksson \& Jemt 2004; Romeo et al. 2008).

To obtain satisfactory esthetic results, immediate implant placement was proposed with the aim of preserving the dimension of the alveolar ridge but it was shown by several studies that implants placed into extraction sockets cannot prevent the post-extraction resorption of the alveolar crest(Caneva et al. 2010). The esthetic outcome of single implants inserted in extraction sockets or healed ridges of the anterior maxilla were compared by a recent retrospective study with a follow-up of 3 years.

Platform-switching concept was introduced in the late 1980s when wide-diameter implants were proposed in combination with standard-diameter abutments and it was observed a reduced peri-implant crestal bone loss (Atieh 
et al. 2010; Chrcanovic et al. 2015; Strietzel et al. 2015). Traditionally, a radiographic marginal bone remodeling of $1.5 \mathrm{~mm}$ during the first year followed by a radiographic MBL of $\leq 0.2 \mathrm{~mm}$ during each succeeding year is an important parameter for the assessment of implant success(Albrektsson et al. 1986).

Several studies had described three rationale stands behind those of PSI as a biomechanical, biologic, and microbiologic feature (Maeda et al. 2007).

The marginal bone remodeling is related to the micro-gap size and location between implant and abutment, and the rational of using an abutment with a smaller diameter than the diameter of the implant shoulder is to locate it more distant to the first bone-implant contact.

The review conducted by(Tallarico et al. 2016) concluded that implant-abutment interface may easily be colonized by bacteria and this, in turn, may lead to peri-implant inflammatory reactions and subsequently the loss of supporting bone (Tsuge et al. 2008; Weng et al. 2008; Schwartz-Arad \& Levin 2005)The repositioning of the IAJ away from the external edge of the implant maintains the inflammatory cell infiltrate away from the adjacent crestal bone (Lazzara \& Porter 2006).

A recent review of literature analyzed the influence of platform-switched implants on marginal bone remodeling and on soft tissue esthetics. The authors concluded that it may be advantageous in situations where a larger implant is desirable but there is a limited prosthetic space or in the anterior zone, where preservation of the crestal bone can improve esthetics (López-Marí et al. 2009).

The aim of this review was to evaluate MBL radiologically and failure rate of implants inserted in post-extraction sites and restored with or without platform switching protocol after one year of prosthetic loading.

\section{Focused question:-}

Does platform-switching provide better implant stability through reducing marginal bone loss that occurs after functional loading?

\section{Methodology:-}

\section{Electronic search:-}

The authors (A.S and M.A) conducted an electronic search on Pubmed to search for eligible studies; till 20 of August 2017. The strategy used was a combination of Mesh terms and text words:

Population:- dental implant[MeSH Terms]) OR immediate implant *[Text Word]))

AND

Intervention:- (((dental implant platform switching[MeSH Terms]) OR platform switching[Text Word]) OR designs, dental implant abutment[MeSH Terms]))

\section{AND}

Outcome:- ((alveolar bone loss[MeSH Terms]) OR marginal bone loss[Text Word])

\section{Hand searching :-}

Hand searching performed by (A.S and M.A) was applied to the Cairo Dental Journal and studies indexed in the Cairo University Library. Also, all relevant papers were retrieved from the bibliography of the included studies and reviews. 


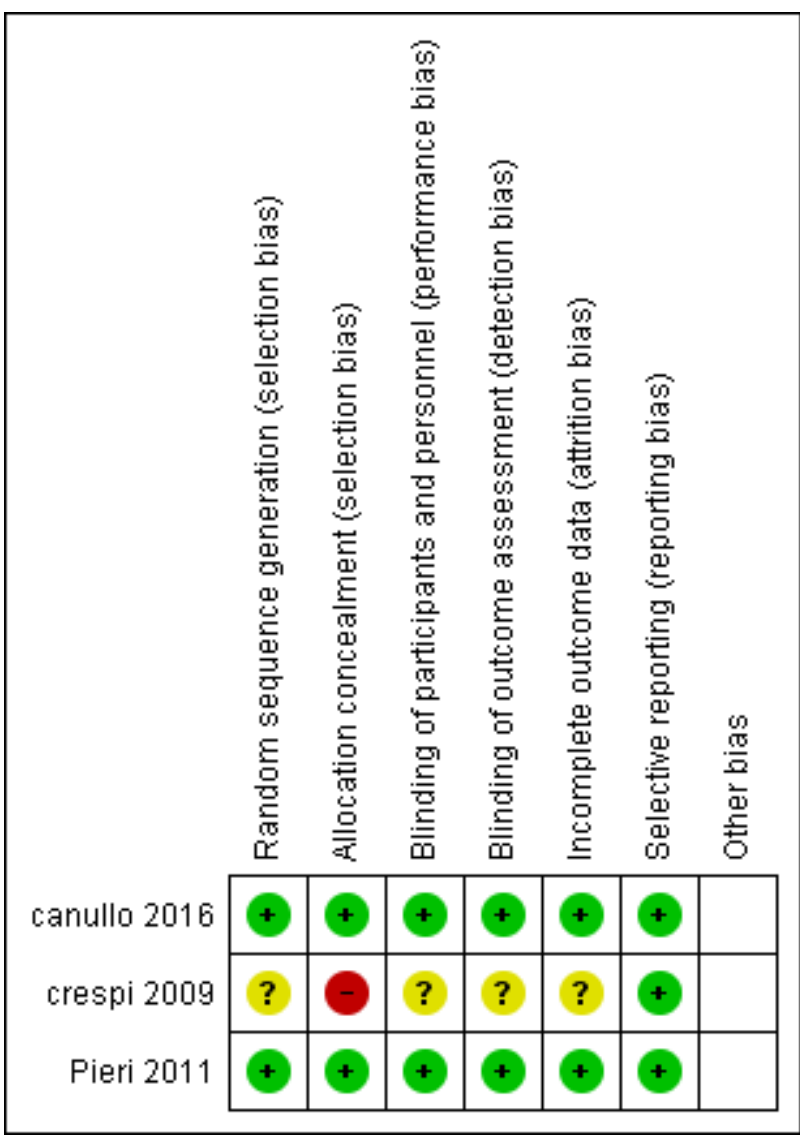

Figure 1:- PRISMA flowchart showing the sequence for identifying the eligible studies. 


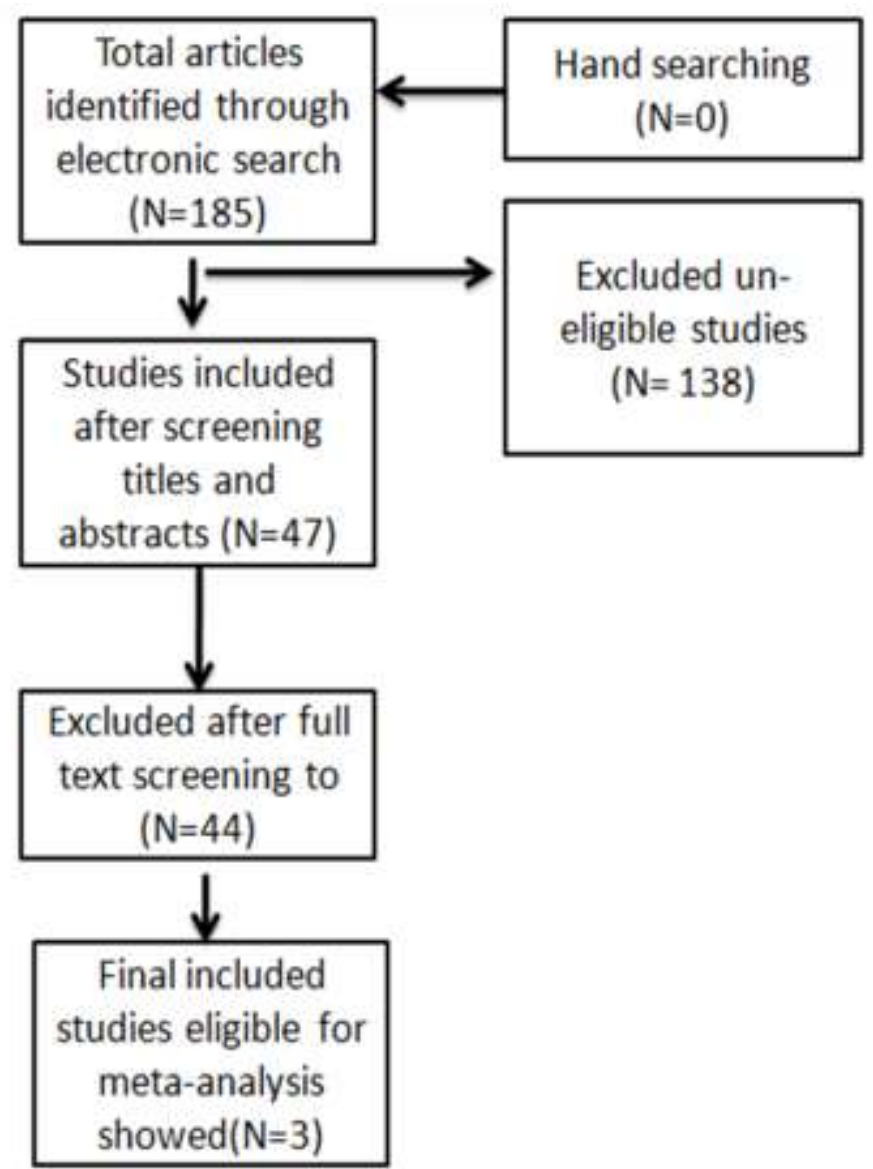

Figure 2: Risk of bias assessment of the included studies

\section{Study Selection:-}

Screening of titles and abstracts was conducted independently by (A.S and M.A); followed by full text screening to check if the studies abide with the pre-set selection criteria which are; patients undergoing dental implant surgery; patients receiving implants with a platform-switching design or regular abutment; articles published in the English language; RCT studies with at least 12 months of follow-up (clinical studies in humans). Any disagreement was solved by discussion between the review authors.

\section{Investigation outcomes:-}

The primary outcome was implant survival rates, while the secondary outcome was the post-surgical marginal bone loss (in both platform-switching and regular platform).

\section{Results:-}

Study Selection:-

The initial electronic search resulted in a total of185 articles (Fig. 1).After screening the titles and abstracts 47 studies were included for further analysis. Reviewing the full text of the remaining articles led to the exclusion of 44 studies. Hand searching did not result in any additional articles. In Table 1 the main characteristics of the 3 included studies.

\section{Quality assessment:-}

A quality assessment of the methodologies of all included studies was conducted. It was based on the randomized controlled trial checklist of the Cochrane Center, CONSORT guidelines (Fig. 2). The following seven criteria were used: selection bias, allocation bias, performance bias, detection bias, defined inclusion/exclusion criteria, attrition bias and reporting bias. If all of these criteria were fulfilled, the article was classified as a low risk of bias (L). If one or two of these criteria were assessed as high risk of bias or unclear, the study was regarded as a moderate potential 
risk of bias (M). The risk of potential bias was high, where three or more criteria had a high or unclear risk of bias $(\mathrm{H})$ as shown in figure (2). The risk of bias was evaluated independently by two reviewers(AS and MA). If there was any disagreement,it was resolved by discussion.

\section{Statistical analyses:-}

Data of the included studies were extracted and entered into Review Manager (RevMan) [Computer program].Version 5.2. Copenhagen: The Nordic Cochrane Centre, the Cochrane Collaboration, 2012.Mean values and standard deviations were extracted from the data. If no standard deviation was available it was recalculated by the formula $(\mathrm{SE}=\mathrm{SD} / \sqrt{ } \mathrm{n}$ ) with $\mathrm{n}$ as the sample size. If there was insufficient data available, the corresponding authors were contacted for providing clarity.

The $\mathrm{I}^{2}$ statistic was used to assess the heterogeneity between the studies. Because of observed heterogeneity mean differences were combined for continuous data using random effects models meta-analysis (The Cochrane Collaboration, 2012). Study weights were determined by the sample size.

\section{Meta-analysis:-}

Primary outcome:-Implant failure.

Two studies reported survival rate 100\% for all implant(Canullo et al. 2016; Crespi et al. 2009). One study reported that the implant success was 100\% in the control group and 94.7\% in the test group(Pieri et al., 2011). In the latter study, two patients (one in the control group and one in the test group) were excluded due to deviations from the protocol: one was excluded because of intraoperative determination of a need for bone grafting to cover a buccal dehiscence after tooth extraction; and one patient failed to comply with the study protocol (the patient missed designated postoperative appointments).

\section{Secondary outcome:-Marginal bone loss}

In this context, the 3 studies showed a statistically significant difference in favor of the use of PS implants for bone preservation(Canullo et al. 2016; Crespi et al. 2009), Pieri et al., 2011)The meta-analysis revealed significant bone loss in the control group compared with the PS group, with a mean difference (MD) of $-0.30 \mathrm{~mm}$ (95\% CI -0.41; $0.19, \mathrm{P}<0.00001$ (Fig. 3). The $\mathrm{Chi}^{2}$ of heterogeneity was $9.44\left(\mathrm{P}<0.00001, \mathrm{I}^{2}=79 \%\right)$.

\begin{tabular}{|c|c|c|c|c|c|c|c|c|c|c|}
\hline \multirow[b]{2}{*}{ Study or Subgroup } & \multicolumn{3}{|c|}{ Experimental } & \multicolumn{3}{|c|}{ Control } & \multicolumn{2}{|r|}{ Mean Difference } & \multirow{2}{*}{\multicolumn{2}{|c|}{$\begin{array}{l}\text { Mean Difference } \\
\text { N, Fixed, 95\% Cl }\end{array}$}} \\
\hline & Mean & SD & Total & Mean & SD & Total & Weight & N, Fixed, $95 \% \mathrm{Cl}$ & & \\
\hline canullo 2016 & 0.18 & 0.14 & 10 & 0.8 & 0.4 & 9 & $15.5 \%$ & $-0.62[-0.90,-0.34]$ & & \\
\hline crespi 2009 & 0.73 & 0.52 & 34 & 0.78 & 0.45 & 30 & $20.8 \%$ & $-0.05[-0.29,0.19]$ & & \\
\hline Pieri 2011 & 0.19 & 0.17 & 19 & 0.49 & 0.25 & 19 & $63.7 \%$ & $-0.30[-0.44,-0.16]$ & & \\
\hline Total (95\% Cl) & & & 63 & & & & $100.0 \%$ & $-0.30[-0.41,-0.19]$ & & \\
\hline $\begin{array}{l}\text { Heterogeneity. } \mathrm{Ch}^{2}= \\
\text { Test for overall effect: }\end{array}$ & $\begin{array}{l}9.44, \mathrm{df} \\
Z=5.38\end{array}$ & $\begin{array}{l}=2 \text { (F } \\
\text { (P }<\end{array}$ & $=0.009$ & $9)_{1}^{2}=70$ & & & & & $\begin{array}{rr}-0.5 & -0 \\
\text { Favours [experin }\end{array}$ & $\begin{array}{cccc}0.25 & 0 & 0.25 & 0.5 \\
\text { mental] } & \text { Favours [control] }\end{array}$ \\
\hline
\end{tabular}

Figure 3:- Forest plot showing the comparison between PS and PM groups regarding marginal bone loss. 
Table 1:-Characteristic of included studies

\begin{tabular}{|c|c|c|c|c|c|c|c|c|}
\hline Author & $\begin{array}{l}\text { No. of } \\
\text { patient } \\
\text { s } \\
\text { F/M }\end{array}$ & $\begin{array}{l}\text { Age } \\
\text { Mean (yrs) } \\
\text { Range }\end{array}$ & $\begin{array}{l}\text { PS/PM } \\
\text { Implant } \\
\text { number } \\
\text { s }\end{array}$ & $\begin{array}{l}\text { Implant } \\
\text { system }\end{array}$ & $\begin{array}{l}\text { Implant } \\
\text { site }\end{array}$ & $\begin{array}{l}\text { Type } \\
\text { of rest- } \\
\text { oration }\end{array}$ & $\begin{array}{l}\text { Margina } \\
1 \\
\text { PS } \\
(\mathrm{mm})\end{array}$ & $\begin{array}{l}\text { Bone loss } \\
\text { PM (mm) }\end{array}$ \\
\hline $\begin{array}{l}\text { Canullo et al., } \\
2016\end{array}$ & $\begin{array}{l}22 \\
\text { patient } \\
\text { s } \\
9 / 13\end{array}$ & $\begin{array}{l}\text { mean }(50 \\
\pm 14.5) \\
\text { range }(32- \\
76)\end{array}$ & $10 / 9$ & $\begin{array}{l}\text { Global } \\
\text { Implant } \\
\text { (Sweden \& } \\
\text { Martina, } \\
\text { Italy). }\end{array}$ & $\begin{array}{l}\text { anterior } \\
\text { region } \\
\text { (3incisors, } \\
3 \text { canines } \\
\text { and } 16 \\
\text { premolars) }\end{array}$ & $\begin{array}{l}\text { metal } \\
\text { cerami } \\
\text { c } \\
\text { crown }\end{array}$ & $\begin{array}{ll}0.18 & \pm \\
0.14 & \end{array}$ & $\begin{array}{l}0.80 \pm 0.4 \\
0\end{array}$ \\
\hline Pieri et al., 2011 & $\begin{array}{l}40 \\
\text { patient } \\
\text { s } \\
25 / 15 \\
\end{array}$ & $\begin{array}{l}\text { mean(46.6 } \\
) \quad \text { range } \\
(32-65)\end{array}$ & $20 / 20$ & $\begin{array}{l}\text { (SamoSmile } \\
\mathrm{r} \text { Implants, } \\
\text { Biospark) }\end{array}$ & $\begin{array}{l}\text { Maxillary } \\
\text { premolar }\end{array}$ & $\begin{array}{l}\text { Single } \\
\text { crown }\end{array}$ & $\begin{array}{ll}0.19 & \pm \\
0.17 & \end{array}$ & $\begin{array}{l}0.49 \\
0.25\end{array}$ \\
\hline $\begin{array}{lll}\text { Crespi et al., } \\
2009\end{array}$ & $\begin{array}{l}45 \\
\text { patient } \\
\text { s } \\
27 / 18 \\
\end{array}$ & $\begin{array}{l}\text { mean } \\
(48.73) \\
\text { range (25- } \\
67)\end{array}$ & $30 / 34$ & NR & $\begin{array}{l}24 \text { in } \\
\text { mandible } \\
40 \text { in } \\
\text { maxilla }\end{array}$ & $\begin{array}{l}\text { splinte } \\
\mathrm{d} \\
\text { crowns }\end{array}$ & $\begin{array}{ll}0.73 & \pm \\
0.52 & \end{array}$ & $\begin{array}{ll}0.78 & \pm \\
0.45 & \end{array}$ \\
\hline
\end{tabular}

\section{Discussion:-}

The objective of the current meta-analyses was to analyze MBL changes around immediately placed dental implants. The Third ITI Consensus Conference (Hämmerleet al. 2004), categorized placement of implants according to the healing time following extraction as: Type 1 immediate (within $24 \mathrm{~h}$ of extraction), Type 2 early (4-8 weeks after extraction), Type 3early-delayed (12-16 weeks after extraction) and Type 4 late (more than 6 months) (Hämmerle and Chen 2004). In this systematic review, the survival rate of Type 1 placements was subject to evaluation.

There are several factors that may affect the outcomes of procedures other than the timing of implant placement. They are either patient-related factors including: the type of the bone; the location and dimension of the edentulous area; the history of oral diseases. Or they could be related to the adopted surgical protocol.

The benefits of PS implants were extensively discussed in the literature (Esposito et al. 2010; Artzi et al. 2013; Esposito et al. n.d.). This yielded considerable number of studies that could be combined in a systematic. The main finding of this study was that the level of bone loss with PS implants was significantly lower than that found with the use of RP implants $(\mathrm{P}<0.00001)$. This is in agreement with the systematic review conducted by(Lang et al. 2012).

The results of meta-analyses are also in accordance to those reported by (Kinaia et al. 2014) where the marginal bone loss showed favorable outcomes for PS group [MBL difference of $-0.242(95 \%$ [CI], -0.403 to $-0.080 ; \mathrm{P}=$ 0.003)] In one randomized clinical controlled trial, significantly less mean bone resorption occurred adjacent to platform-switched abutment restorations than that found at sites using platform-matched abutments (Canullo et al. 2009). However, in another RCT, no such differences were demonstrated (Crespi et al. 2009). Hence, more clinical trials are required to confirm the possible benefits of the platform-switching technique.

On the long run, good oral hygiene is a prerequisite for maintaining bone levels. With low plaque and mucositis levels, bone levels even improved (mean gain of $0.2 \mathrm{~mm}$ ) after 5 years of implant functioning (Botticelli et al. 2004; Caneva et al. 2010).

\section{Conclusions:-}

Within the limitations of the present systematic review, the additional benefit of platform-switching should not be under estimated. Although the meta-analyses showed significant difference in favor of PS, however, the considerable heterogeneity should be beared in mind when drawing the results on greater population. The language constraints, limiting the included studies to English language, may have caused missing some data that could have 
added to the body of evidence. Further studies that are properly conducted are recommended for better evaluation of the true tangible effect of platform-switching.

\section{Disclaimer:-}

The review authors report no conflict of interest. This study was self-funded

\section{Bibliography:-}

1. Albrektsson, T. et al., 1986. The long-term efficacy of currently used dental implants: a review and proposed criteria of success. The International journal of oral \& maxillofacial implants, 1(1), pp.11-25. Available at: http://www.ncbi.nlm.nih.gov/pubmed/3527955 [Accessed October 21, 2017].

2. Artzi, Z. et al., 2013. Timing of Implant Placement and Augmentation with Bone Replacement Material: Clinical Assessment at 8 and 16Months. Clinical Implant Dentistry and Related Research, 15(1), pp.121-129.

3. Atieh, M.A., Ibrahim, H.M. \& Atieh, A.H., 2010. Platform Switching for Marginal Bone Preservation Around Dental Implants: A Systematic Review and Meta-Analysis. Journal of Periodontology, 81(10), pp.1350-1366. Available at: http://www.ncbi.nlm.nih.gov/pubmed/20575657 [Accessed October 21, 2017].

4. Botticelli, D., Berglundh, T. \& Lindhe, J., 2004. Hard-tissue alterations following immediate implant placement in extraction sites. Journal of Clinical Periodontology, 31(10), pp.820-828.

5. Caneva, M. et al., 2010. Hard tissue formation adjacent to implants of various size and configuration immediately placed into extraction sockets: An experimental study in dogs. Clinical Oral Implants Research, 21(9), pp.885-890.

6. Canullo, L., Caneva, M. \& Tallarico, M., 2016. Ten-year hard and soft tissue results of a pilot double-blinded randomized controlled trial on immediately loaded post-extractive implants using platform-switching concept. Clinical Oral Implants Research, pp.1-9.

7. Chrcanovic, B.R., Albrektsson, T. \& Wennerberg, A., 2015. Platform switch and dental implants: A metaanalysis. Journal of Dentistry, 43(6), pp.629-646. Available at: http://www.ncbi.nlm.nih.gov/pubmed/25559693 [Accessed October 21, 2017].

8. Cooper, L.F. et al., 2007. Three-Year Evaluation of Single-Tooth Implants Restored 3 Weeks After 1-Stage Surgery. The International Journal of Oral \& Maxillofacial Implants, 16(2), pp.791-800.

9. Crespi, R., Capparè, P. \& Gherlone, E., 2009. Radiographic evaluation of marginal bone levels around platform-switched and non-platform-switched implants used in an immediate loading protocol. The International journal of oral \& maxillofacial implants, 24(5), pp.920-926.

10. Esposito, M. et al., Dental implants with internal versus external connections: 5-year post-loading results from a pragmatic multicenter randomised controlled trial. European journal of oral implantology, 9 Suppl 1(2), pp.129-41. Available at: http://www.ncbi.nlm.nih.gov/pubmed/27314118 [Accessed October 20, 2017].

11. Esposito, M. et al., 2010. Timing of implant placement after tooth extraction: immediate, immediate-delayed or delayed implants? A Cochrane systematic review. European journal of oral implantology, 3(3), pp.189-205.

12. Hämmerle CH, Chen ST, W.T.J., 2004. Consensus statements and recommended clinical procedures regarding the place- ment of implants in extraction sockets. Int J Oral Maxillofac Implants, 19(Suppl), pp.26-28.

13. Henriksson, K. \& Jemt, T., 2004. Measurements of soft tissue volume in association with single-implant restorations: a 1-year comparative study after abutment connection surgery. Clinical implant dentistry and related research, 6(4), pp.181-9. Available at: http://www.ncbi.nlm.nih.gov/pubmed/15841578 [Accessed October 21, 2017].

14. Kinaia, B.M. et al., 2014. Crestal Bone Level Changes Around Immediately Placed Implants: A Systematic Review and Meta-Analyses With at Least 12 Months' Follow-Up After Functional Loading. Journal of Periodontology, 85(11), pp.1537-1548. Available at: http://www.ncbi.nlm.nih.gov/pubmed/24794689 [Accessed October 20, 2017].

15. Lang, N.P. et al., 2012. A systematic review on survival and success rates of implants placed immediately into fresh extraction sockets after at least 1 year. Clinical Oral Implants Research, 23, pp.39-66. Available at: http://www.ncbi.nlm.nih.gov/pubmed/22211305 [Accessed October 20, 2017].

16. Lazzara, R.J. \& Porter, S.S., 2006. Platform switching: a new concept in implant dentistry for controlling postrestorative crestal bone levels. The International journal of periodontics \& restorative dentistry, 26(1), pp.9-17. Available at: http://www.ncbi.nlm.nih.gov/pubmed/16515092 [Accessed October 21, 2017].

17. López-Marí, L. et al., 2009. Implant platform switching concept: an updated review. Medicina oral, patologia oral y cirugia bucal, 14(9), pp.e450-4. Available at: http://www.ncbi.nlm.nih.gov/pubmed/19718008 [Accessed October 21, 2017]. 
18. Maeda, Y. et al., 2007. Biomechanical analysis on platform switching: is there any biomechanical rationale? Clinical Oral Implants Research, 18(5), pp.581-584. Available at: http://www.ncbi.nlm.nih.gov/pubmed/17608737 [Accessed October 21, 2017].

19. Romeo, E. et al., 2008. Surgical and prosthetic management of interproximal region with single-implant restorations: 1-year prospective study. Journal of periodontology, 79(6), pp.1048-55. Available at: http://www.joponline.org/doi/10.1902/jop.2008.070431 [Accessed October 21, 2017].

20. Schropp, L. et al., 2003. Bone healing and soft tissue contour changes following single-tooth extraction: a clinical and radiographic 12-month prospective study. The International journal of periodontics \& restorative dentistry, 23(4), pp.313-323.

21. Schwartz-Arad, D. \& Levin, L., 2005. Intraoral autogenous block onlay bone grafting for extensive reconstruction of atrophic maxillary alveolar ridges. The Journal of periodontology, 76(4), pp.636-641. Available at: http://www.joponline.org/doi/abs/10.1902/jop.2005.76.4.636.

22. Strietzel, F.P., Neumann, K. \& Hertel, M., 2015. Impact of platform switching on marginal peri-implant bonelevel changes. A systematic review and meta-analysis. Clinical oral implants research, 26(3), pp.342-58. Available at: http://doi.wiley.com/10.1111/clr.12339 [Accessed October 21, 2017].

23. Tsuge, T., Hagiwara, Y. \& Matsumura, H., 2008. Marginal fit and microgaps of implant-abutment interface with internal anti-rotation configuration. Dental materials journal, 27(1), pp.29-34. Available at: http://www.ncbi.nlm.nih.gov/pubmed/18309609 [Accessed October 21, 2017].

24. Weng, D. et al., 2008. Influence of microgap location and configuration on the periimplant bone morphology in submerged implants. An experimental study in dogs. Clinical oral implants research, 19(11), pp.1141-7. Available at: http://doi.wiley.com/10.1111/j.1600-0501.2008.01564.x [Accessed October 21, 2017]. 